J. Product. \& Dev., 19(1):61 - 76(2014)

\title{
IMPACT OF ZINC FORTIFIED YOGHURT ON ACUTE PNEUMONIA IN CHILDREN
}

\author{
A.M. Elshawaf"; A.R. Elzainy ${ }^{* * *}$; D.M. Shokry ${ }^{* * *}$ and Yomna A. Elazawy ${ }^{* * *}$ \\ * Department of Food and Dairy Sciences, Faculty of Technology and \\ Development, Zagazig University, Egypt. \\ ** Department of Home Economics, Faculty of Specific Education, Zagazig \\ University, Egypt. Email: y_elazawy@hotmail.com \\ **** Department of Pediatrics, Faculty of Medicine, Zagazig University, Egypt.
}

\section{ABSTRACT}

Zinc (Zn) has a role in the acute phase response to infection helping to boost the body's immune response through a defense cascade. The objective was a trial to assess the effect of $\mathrm{Zn}$ supplemented yoghurt, when given with routine hospital treatment, on reducing treatment failure, length of hospital stay, and duration of symptoms of pneumonia in children less than five years old. 45 children suffered from acute severe pneumonia were subjected to complete physical exam and randomized to receive either $\mathrm{Zn}$ supplemented yoghurt $20 \mathrm{mg} \mathrm{Zn}$-acetate "= $6 \mathrm{mg} \mathrm{Zn}$ element" (group-B, $n=15)$ or $20 \mathrm{mg} Z \mathrm{Zn}$ element "= $66 \mathrm{mg} \mathrm{Zn}$-acetate” (group$C, n=15)$ per $240 \mathrm{ml}$ yoghurt divided into 2 or 4 meals/day according to child appetite) or placebo (group- $A, n=15)$ and followed up until they were discharged from the hospital. Serum Zn, hemoglobin percent and C-Reactive Protein were measured once on admission (before supplementation) for all and serum $\mathrm{Zn}$ on discharge (after supplementation) for group-B and group-C only.

The results revealed that there was no statistical significant difference between the 3 manufactured zinc-supplemented yoghurt samples as regard chemical and physical properties and no statistical significant difference between the 3 groups as regards age, sex, length/height, weight, nutritional history, clinical picture and serum $\mathrm{Zn}$ on admission. There was no mortality in the 3 groups. Serum Zn was significantly increased in group- $B$ \& group- $C$ on discharge while hospital days for improvement and total hospital stay were shorter in group-B and group-C than placebo. Hospital day for improvement in group- $A$ is significantly longer than that of group-B and highly 
significantly than in group-C while the total hospital days in group-A is highly significantly longer than that of group-C only. There was no significant negative correlation between serum $\mathrm{Zn}$ after and hospital days for improvement and a significant one with total hospital days.

Conclusively, from these results it could be concluded that Zn-supplemented yoghurt decreases the duration of hospital stay, and duration of symptoms of severe pneumonia in best treatment dose of $6 \mathrm{mg} /$ day and more effectively in dose of $20 \mathrm{mg} /$ day of $\mathrm{Zn}$ as nutrient element.

Keywords: Zinc Fortified Yoghurt, Acute Pneumonia, Children.

\section{INTRODUCTION}

Zinc is an essential element, necessary for sustaining all life. It is estimated that 3000 of the hundreds of thousands of proteins in the human body contain zinc prosthetic groups. Zinc is found in oysters, and to a far lesser degree in most animal proteins, beans, nuts, almonds, whole grains, pumpkin seeds and sunflower seeds. Phytates, which are found in whole grain breads, cereals, legumes and other products, have been known to decrease zinc absorption. Zinc deficiency results from inadequate intake of zinc, or inadequate absorption of zinc into the body (Aydemir et al., 2006).

Experience with lower mortality and morbidity due to infectious disease in well-designed, randomized, controlled trials of zinc supplements in young children has highlighted zinc deficiency as a public health problem of global proportions (Jones et al., 2003). Zinc administered as a therapeutic agent to young children with acute or persistent diarrhea also reduces the duration of the diarrhea and is associated with a lower rate of treatment failure or death (Bhutta et al., 2000).

However, results of studies of zinc administered as adjuvant therapy for pneumonia have been more limited.

Zinc might act in the acute phase response to infection (Ling et al., 1996 and Gaetke et al., 1997) helping to boost the body's immune response through a defence cascade, beginning with mobilisation and sequestration of zinc to metallothionein-rich tissue, rapid up regulation of immune defencespecific protein synthesis, activation of immune defence activity such as macrophages, lymphocytes, and natural killer cells, and antibody-dependent cytotoxicity (Cousins, 1985). 


\section{Aim of study:}

It was to assess the effect of zinc supplemented yoghurt, when given with antibiotics, in duration of symptoms of severe pneumonia, length of hospital stay and change of serum zinc level in children less than five years old.

\section{Subjects:}

This is a double blind randomized placebo-controlled clinical study done in the Pediatric Zagazig University, In patient Hospital from Sep. 2008 to Sep. 2010. Hundred children suffered from severe pneumonia between 2 and 5 years old at the time of admission were randomized to receive zinc supplemented yoghurt or plain yoghurt plus the hospitals standard antimicrobial management until discharge.

The age-group 2-5 years was selected for its ability to feed, high pneumonia morbidity and restricted options to prevent community-acquired bacterial pneumonia. A fixed dose of $20 \mathrm{mg}$ of elemental zinc per day was chosen because this is the dose being adopted for programmatic use in diarrhea case management (Fontaine, 2001). Additionally the median mg/kg exposure for this age-group was estimated to fall well below the range of acute toxicity (Fosmire, 1990).

A study physician did a baseline physical examination, including timing of respiratory rate, assessment of breathing effort, cyanosis, mental status, and chest auscultation of crepitation or wheezing, or both. Axillary temperature was taken with a mercury thermometer.

Inclusion criteria: Children aged 2-5 years were considered eligible for enrollment in the study if they fulfilled the criteria for a diagnosis of severe bacterial pneumonia. Severe pneumonia was defined as a respiratory rate more than 40/min, which was accompanied with crepitations on auscultation and the presence of one or more of the following danger signs; lethargy, inability to feed, chest indrawing, or central cyanosis (Bose et al., 2006). Bacterial pneumonia was defined as pneumonia with $\mathrm{C}$-reactive protein concentrations more than $40 \mathrm{mg} / \mathrm{L}$ (Coles et al., 2007). Consent was obtained by a study physician who read the entire consent form to the parent.

Exclusion criteria: Children were excluded if they had concurrent diarrhea, were receiving zinc supplements, or had severe malnutrition, inability to feed, history of chronic cardiac or renal disease, illness severe enough to require ventilation and illness requiring hospitalization in the previous 21 days or failure of taking regular $20 \mathrm{mg}$ zinc supplemented meals /day. 


\section{Treatment groups:}

Children were then randomized to three groups: First group-A had been received placebo yoghurt, Second group-B had been received zinc supplemented yoghurt in a dose of $20 \mathrm{mg}$ zinc-acetate that equal $6 \mathrm{mg}$ zinc element per $240 \mathrm{ml}$ yoghurt and third group- $C$ had been received zinc supplemented yoghurt in a dose of $66 \mathrm{mg}$ zinc-acetate that equal $20 \mathrm{mg}$ zinc element per $240 \mathrm{ml}$ yoghurt.

The yoghurt was divided into 2 or 4 meals / day according to child appetite until they were discharged from the hospital. The supplement preparations were administered at the time of enrolment, within $1 \mathrm{~h}$ of the first dose of parenteral antibiotics on admission day. The placebo and zincsupplemented yoghurt were approximately similar in appearance, color, odor, and taste. The zinc and placebo yoghurt were prepared and labeled A, B and $\mathrm{C}$ respectively by the researcher.

\section{Follow up:}

Data for respiratory rate, chest indrawing, auscultation findings, fever, feeding, cyanosis, and mental status, were obtained at the beginning of every nursing shift (8h). All enrolled patients were managed according to the Hospital's standard severe pneumonia treatment guidelines. Parenteral antibiotics were ampicillin (200-400 mg/kg of body weight per day, given intravenously every 6h) and gentamicin (6-7.5 $\mathrm{mg} / \mathrm{kg}$ per day, given intravenously every 8h). Patients who failed to improve after $48 \mathrm{~h}$ of antibiotics (by the eighth dose of ampicillin) or whose condition worsened, had their antibiotic changed to ceftriaxone $(50 \mathrm{mg} / \mathrm{kg}$ per day intravenously).

Failure to improve and worsening condition were established by respiratory rate count and severe pneumonia signs. Worsening of any one sign qualified as worsening condition and no change in any sign constituted failure to improve. Although fever was not necessary for diagnosis, it was taken as a sign of active infection, and thus had to be absent for 24 consecutive hours without the aid of antipyretics to qualify for change from severe to non-severe pneumonia.

Severe pneumonia was reclassified to pneumonia (non-severe) when chest indrawing and hypoxia (oxygen saturation less than $95 \%$ on room air) were absent for 24 consecutive hours and respiratory rate was less than or equal to 40 breaths per min, at which time oral antibiotics were started. The oral antibiotic was amoxicillin $40 \mathrm{mg} / \mathrm{kg}$ divided every $8 \mathrm{~h}$. If any sign recurred, the child was reclassified as severe status until these conditions were met. 
Children were discharged from hospital once respiratory rate fell to less than or equal to 40 per min for 24 consecutive hours, with no recurrence of respiratory distress, other danger signs, or fever (temperature $>37.9^{\circ} \mathrm{C}$ ). Before discharge $3 \mathrm{~mL}$ of blood was drown from every child for measurement of post-intervention serum zinc concentration in group $\mathrm{B}$ and $\mathrm{C}$.

\section{MATERIALS:}

\section{Buffalo's milk:}

Fresh whole buffalo's milk was obtained from Dairy Laboratory, Faculty of Agriculture, Zagazig University.

\section{Zinc acetate:}

Zinc acetate (extra pure dihydrate) was obtained from Loba Chemie PVT.LTD .www.lobachemie.com(INDIA).

\section{Human blood samples:}

Three $\mathrm{mL}$ blood sample was obtained from every patient at the time of admission for measuring serum zinc level. Another two ml blood sample was collected in EDTA (ethylenediaminetetraacetic acid) tubes for measuring blood hemoglobin percent.

\section{METHODS:}

\section{Bio-yoghurt manufacture:}

Yoghurt starter culture (Yo-Flex, YC-350, direct vat starter (DVS)) consists of Streptococcus thermophilus, L. delbrueckii subsp.bulgaricus; probiotic bacteria, L. acidophilus La-5 and Bifidobacterium (B.) lactis Bb-12 ( $D V S$ ) were obtained from Chr. Hansen's Lab A/S Copenhagen Denmark.

Fresh buffalo milk was heated at $90 \mathrm{C}$ for $5 \mathrm{~min}$, then cooled to $37 \mathrm{C}$; inoculated with yoghurt starter, L. acidophilus La-5 and B. lactis Bb-12 at $0.01,0.025$ and $0.025 \%$, respectively (Chandand and O'Rell, 2006).

The milk was divided into three portions: the first portion (A) was regarded as placebo (plain yoghurt), the second portion (B) was fortified with zinc acetate at a level of $20 \mathrm{mg} / 240 \mathrm{ml}$ and the third portion (C) was fortified with zinc acetate at a level of $66 \mathrm{mg} / 240 \mathrm{ml}$. Each portion was distributed in $60 \mathrm{ml}$ plastic cups(labeled A orb accordingly), the cups closed and incubated at $37{ }^{\circ} \mathrm{C}$ until a firm curd was formed (5.5h) then kept in a refrigerator to be served to the patient within $24 \mathrm{~h}$. 


\section{Chemical analysis and serum zinc:}

$\mathrm{Zn}$ and major elements concentration in the three yoghurt samples (A, B and C) were carried out in Central Laboratory of Faculty of Veterinary Medicine, Zagazig University using Atomic Absorption Spectrophotometer (model 210VGP, buck Scientific USA) with an oxidizing air acetylene flame (A.O.A.C, 1990). Titratable acidity, total solids, protein and fat were determined according to Ling (1963). $\mathrm{pH}$ value was measured using a $\mathrm{pH}$ meter (PTI-15, Aqua Chemical Co., England).

Microbiological analysis was done by using selenite cystine broth For Salmonella agar media for total viable count of bacteria, lactic acid bacteria, Streptococcus; Salmonella; Staphylococcus aureus and spores incubated both aerobically and anaerobically; MRS agar containing 10mg ml-1 nystatin selective for lactic acid bacteria; M-17 agar selective for Streptococcus, Brilliant green, xylose lysine decarboxylate, and bismuth sulphite agar selective for Salmonella spp.; Mannitol salt agar- selective for staphylococci; Baird Parker agar selective for Staphylococcus aureus (Harrigan \& Mc Cane, 1976).

\section{Measurement of blood hemoglobin (Hb\%):}

It was performed at Central Laboratory of Faculty of Medicine, Zagazig University by using automated blood cell counter (Sysmex, Sysmex corporation, Kobe, Japan) to all patients within $24 \mathrm{~h}$ admission.

\section{Statistical analysis:}

The statistical calculations were done using Computer Programs Microsoft Excel Version 14.0 (Microsoft Corporation 2010, NY, USA) and SPSS Version 17.0 ( Statistical Package for the Social Science; SPSS inc, Chicago, IL, USA) for Microsoft Windows (Andy, 2005).

\section{RESULTS AND DISCUSSION}

Data in Table 1 revealed no apparent differences between the three samples as regard to the chemical and physical properties. In agreement with the present results of plain-yoghurt sample were Omer (2004) and Osman (2004) $\mathrm{pH}$, titratable acidity, total solids protein fat, total ash , Zn, P, Mg and $\mathrm{Ca}$, as well as, flavour, odour, color, and consistency of plain and zinc fortified bio-yoghurt Samples were determined. 
Table 1: Chemical composition and physical properties of yoghurt

\begin{tabular}{|c|c|c|c|}
\hline $\mathrm{X}$ & & Zn acet & Supplemented \\
\hline Properties & (A) & $\begin{array}{c}20 \mathrm{mg} / 240 \mathrm{ml} \\
\text { (B) }\end{array}$ & $\begin{array}{c}66 \mathrm{mg} / 240 \mathrm{ml} \\
(\mathrm{C})\end{array}$ \\
\hline $\begin{array}{l}\text { Chemical: } \\
\mathrm{pH}\end{array}$ & 4.39 & 4.35 & 4.40 \\
\hline $\begin{array}{l}\text { Titratable acidity, } \\
\text { gm/100mL }\end{array}$ & 1.13 & 1.13 & 1.14 \\
\hline Total solid /100mL & 15.30 & 15.31 & 15.33 \\
\hline Fat $\mathrm{gm} / 100 \mathrm{~mL}$ & 5.38 & 5.40 & 5.39 \\
\hline Protein, gm/100mL & 4.70 & 4.75 & 4.73 \\
\hline Total ash, gm/100mL & 0.80 & 0.82 & 0.93 \\
\hline $\mathrm{Zn}, \mathrm{mg} / 100 \mathrm{~mL}$ & 0.49 & 2.9 & 8.7 \\
\hline $\mathrm{P}, \mathrm{gm} / 100 \mathrm{~mL}$ & 9.10 & 9.09 & 9.11 \\
\hline $\mathrm{Mg}, \mathrm{gm} / 100 \mathrm{~mL}$ & 1.30 & 1.33 & 1.31 \\
\hline $\mathrm{Ca}, \mathrm{gm} / 100 \mathrm{~mL}$ & 13.70 & 13.69 & 13.71 \\
\hline $\begin{array}{l}\text { Physical (sensory): } \\
\text { Flavor }\end{array}$ & Normal & Normal & Undetectable metallic \\
\hline Odour & Normal & Normal & Normal \\
\hline Consistency & Soft & Soft & Slightly firmer \\
\hline Color & Whitish & Whitish & Whitish \\
\hline
\end{tabular}

Values are means of three independent determinations.

On the other hand, Fuentea et al. (2003) examined the content of major minerals (calcium, magnesium, phosphorus and zinc) of 16 commercial yoghurts from five different branches and recorded different results than ours due to addition of different dairy products or fractions during manufacturing.

Data in Table 2 revealed no apparent microbiological differences between the three samples of yoghurt because we used only fresh samples (< $48 \mathrm{hr}$ ) during this study. Approximately this agreed with Laye et al. (2006) who found that viable bacteria concentrations ranged from 140 to $8,000 \times$ $10^{6} / \mathrm{g}$ and ratios of lactobacillus to streptococcus ranged from 0.18 to 15.4 . 
Table 2: Total microbial viable count $\left(\mathrm{cfu}^{-1}\right)$ of the three buffalo milk yogurt samples (A, B \& $C)$.

\begin{tabular}{|c|c|c|c|}
\hline \multirow[b]{2}{*}{ Type of bacteria } & \multirow{2}{*}{$\begin{array}{l}\text { Plain } \\
\text { (A) }\end{array}$} & \multicolumn{2}{|c|}{ Zn acetate Supplemented } \\
\hline & & $\begin{array}{l}20 \mathrm{mg} / 240 \mathrm{ml} \\
\text { (B) }\end{array}$ & $\begin{array}{c}66 \mathrm{mg} / 240 \mathrm{ml} \\
\text { (C) }\end{array}$ \\
\hline Total bacterial count & $2.59 \times 10^{5}$ & $2.60 \times 10^{5}$ & $2.59 \times 10^{5}$ \\
\hline Staphylococcus aureus & ND & ND & ND \\
\hline Streptococcus & $1.60 \times 10^{6}$ & $1.61 \times 10^{6}$ & $1.61 \times 10^{6}$ \\
\hline Lactobacillus & $1.72 \times 10^{5}$ & $1.73 \times 10^{5}$ & $1.71 \times 10^{5}$ \\
\hline Coliform & 149 & 150 & 149 \\
\hline Escherichia coli & 62 & 62 & 61 \\
\hline Salmonella spp. & ND & ND & ND \\
\hline
\end{tabular}

Values are means of three independent determinations.

Cfu g $^{-1}$ : Colony-forming units per gram. ND: Not detect.

In Eissa et al. (2010) results revealed that the increment of the acidity of the growth media with the storage time may retard the bacterial growth. These results are in agreement with the findings of Masud et al. (1991).

Data in Table (3) shows that there is no significant difference between the three groups as regard age, hieght and weight $(\mathrm{P}>0.05)$ by ANOVA test. Also there is no significant difference between the 3 groups as regard sex distribution, nutritional history and pneumonia types by Chi- Square. So we can say that the three groups were homogeneous to exclude the effect of these factors on the course of the disease, as Chia-Ni Lina et al. (2012) found that there was no significant effect of gender on serum zinc, which concerned in the present study.

From these results in Table 4, it could be concluded that the three studied groups are homogeneous as regard the severity of the condition (temperature, pulse and respiratory rate) and hemoglobin level by ANOVA test and the clinical manifestations (wheezy chest and signs of dehydration) showed no significant statistical difference by Chi Square test.

So from the previous results in Tables $3 \& 4$, the baseline characteristics of the children were well balanced between the placebo (group-A) and the zinc treated groups (group-B \& group-C). 
Table 3: Comparison between the three groups as regard of age, height $\&$ weight by ANOVA test and gender, nutritional history \& type of pneumonia by Chi- Square test.

\begin{tabular}{|c|c|c|c|c|c|}
\hline $\begin{array}{ll} & \text { Groups } \\
\text { Items }\end{array}$ & $\begin{array}{c}\text { Group A } \\
n=15\end{array}$ & $\begin{array}{c}\text { Group B } \\
n=15\end{array}$ & $\begin{array}{c}\text { Group C } \\
n=15\end{array}$ & Test & $\mathbf{P}$ \\
\hline $\begin{array}{r}\text { Age } / \mathrm{mo} \\
\text { Mean } \pm \text { SD } \\
\text { Range }\end{array}$ & $\begin{array}{c}32.2 \pm 8.92 \\
24-55\end{array}$ & $\begin{array}{c}32.13 \pm 6.46 \\
24-45\end{array}$ & $\begin{array}{c}30.30 \pm 6.42 \\
24-45\end{array}$ & $\begin{array}{c}\mathbf{F} \\
0.31\end{array}$ & 0.735 \\
\hline $\begin{array}{r}\text { Weight / kg } \\
\text { Mean } \pm \text { SD } \\
\text { Range }\end{array}$ & $\begin{array}{c}12.76 \pm 1.57 \\
11.0-16.0\end{array}$ & $\begin{array}{c}12.83 \pm 1.39 \\
11.0-15.5\end{array}$ & $\begin{array}{l}12.53 \pm 1.40 \\
11.0-15.5\end{array}$ & $\begin{array}{c}\mathbf{F} \\
0.174\end{array}$ & 0.841 \\
\hline $\begin{array}{r}\text { Length / cm } \\
\text { Mean } \pm \text { SD } \\
\text { Range }\end{array}$ & $\begin{array}{l}90.00 \pm 6.95 \\
82.0-103.0\end{array}$ & $\begin{array}{c}89.86 \pm 6.40 \\
80.0-89.0 \\
\end{array}$ & $\begin{array}{c}88.66 \pm 6.34 \\
80.0-99.0 \\
\end{array}$ & $\begin{array}{c}\mathbf{F} \\
0.257\end{array}$ & 0.775 \\
\hline $\begin{array}{r}\text { Female } \\
\text { Male }\end{array}$ & $\begin{array}{l}\mathrm{n}=7(46.7 \%) \\
\mathrm{n}=8(53.3 \%)\end{array}$ & $\begin{array}{l}\mathrm{n}=7(46.7 \%) \\
\mathrm{n}=8(53.3 \%)\end{array}$ & $\begin{array}{l}\mathrm{n}=7(46.7 \%) \\
\mathrm{n}=8(53.3 \%)\end{array}$ & $\begin{array}{c}\chi^{2} \\
0.000\end{array}$ & 1.000 \\
\hline $\begin{array}{r}\text { Nutr. History: } \\
\text { Not accepted } \\
\text { Accepted }\end{array}$ & $\begin{array}{c}\mathrm{n}=5(33.3 \%) \\
\mathrm{n}=10(66.7 \%)\end{array}$ & $\begin{array}{l}\mathrm{n}=6(40.0 \%) \\
\mathrm{n}=9(60.0 \%)\end{array}$ & $\begin{array}{l}\mathrm{n}=6(40.0 \%) \\
\mathrm{n}=9(60.0 \%)\end{array}$ & $\begin{array}{c}\chi^{2} \\
0.189\end{array}$ & 0.910 \\
\hline $\begin{array}{r}\text { Pneumonia types } \\
\text { Lober - } \\
\text { Broncho - }\end{array}$ & $\begin{array}{l}\mathrm{n}=7(47.7 \%) \\
\mathrm{n}=8(53.3 \%)\end{array}$ & $\begin{array}{l}\mathrm{n}=6(40.0 \%) \\
\mathrm{n}=9(60.0 \%)\end{array}$ & $\begin{array}{l}n=6(40.0 \%) \\
n=9(60.0 \%)\end{array}$ & $\begin{array}{c}\chi^{2} \\
1.514\end{array}$ & 0.469 \\
\hline
\end{tabular}

n: Number, F: ANOVA test, P: Probability, SD: Standard Deviation, mo: Month, g: Kilogram, cm: Centimeter, $\chi^{2}$ : Chi- Square.

Results in Table (5) shows that the serum zinc before the manipulation and duration of disease before admission have no statistical significant difference $(\mathrm{P}=0.800)$ between the three groups so the three groups are homogeneous as regard this factor. While the serum zinc after the manipulation (at day of discharge) shows a statistically significant increase in group- $\mathrm{C}$ than group- $\mathrm{B}(\mathrm{P}=0.000)$.

There is a significant difference as regard hospital days for improvement from severity $(\mathrm{P}=0.026)$ by ANOVA. By LSD hospital days for improvement in group-A is significantly longer than that of group-B and group- $C$ while there is no significant difference between group-B and groupC. Also the total hospital admission days shows a significant difference between the three groups by ANOVA test $(\mathrm{P}=0.006)$. By LSD total hospital 
Table 4: Comparison among the three groups (Mean \pm SD) temperature, pulse, respiratory rate (RR) \& blood hemoglobin (HB) by ANOVA - Test and presence of wheezy chest $\&$ signs of dehydration by Chi Square test.

\begin{tabular}{|c|c|c|c|c|c|}
\hline Items & $\begin{array}{r}\text { Gro } \\
\mathbf{n}=\end{array}$ & $\begin{array}{c}\text { Gro } \\
\mathbf{n}=\end{array}$ & $\begin{array}{l}\text { Grol } \\
\mathbf{n}=\end{array}$ & Test & $\mathbf{P}$ \\
\hline $\begin{array}{r}\text { Temperature } / c^{\circ} \\
\text { Mean } \pm \text { SD } \\
\text { Range }\end{array}$ & $\begin{array}{l}38 . \\
37 .\end{array}$ & & $\begin{array}{r}38.5 \\
37 .\end{array}$ & $\begin{array}{c}\mathbf{F} \\
0.146\end{array}$ & 0.864 \\
\hline $\begin{array}{r}\text { Pulse / min } \\
\text { Mean } \pm \text { SD } \\
\text { Range } \\
\end{array}$ & $\begin{array}{r}131.6 \\
110 \\
\end{array}$ & $\begin{array}{r}132.6 \\
11 \\
\end{array}$ & $\begin{array}{r}135 . \\
110 \\
\end{array}$ & $\begin{array}{c}\mathbf{F} \\
0.365\end{array}$ & 0.696 \\
\hline $\begin{array}{r}R R / \min \\
\text { Mean } \pm \text { SD } \\
\text { Range }\end{array}$ & $\begin{array}{r}56.06= \\
46\end{array}$ & $\begin{array}{r}61.2 \pm \\
48-\end{array}$ & $\begin{array}{c}62.33 \pm 5.82 \\
48-69\end{array}$ & $\begin{array}{c}\mathbf{F} \\
3.439\end{array}$ & $0.041 *$ \\
\hline $\begin{array}{r}\text { HB gm\% } \\
\text { Mean } \pm \text { SD } \\
\text { Range }\end{array}$ & $\begin{array}{r}11.02= \\
8.6-\end{array}$ & $\begin{array}{r}11.6 \\
9.0\end{array}$ & $\begin{array}{c}10.84 \pm 1.017 \\
9.0-13.0\end{array}$ & $\begin{array}{c}\mathbf{F} \\
0.174\end{array}$ & 0.841 \\
\hline $\begin{array}{rr}\text { Wheezy chest } & \\
& \text { No } \\
& \text { Yes }\end{array}$ & $\begin{array}{l}n=8(53.3 \%) \\
n=7(46.7 \%)\end{array}$ & $\begin{array}{l}n=9(60.0 \%) \\
n=6(40.0 \%)\end{array}$ & $\begin{array}{l}\mathrm{n}=8(53.3 \%) \\
\mathrm{n}=7(46.7 \%)\end{array}$ & $\begin{array}{c}\chi^{2} \\
0.180\end{array}$ & 0.914 \\
\hline $\begin{array}{r}\text { Signs of dehydration } \\
\text { No } \\
\text { Yes }\end{array}$ & $\begin{array}{c}\mathrm{n}=12(80.0 \%) \\
\mathrm{n}=3(20.0 \%)\end{array}$ & $\begin{array}{c}\mathrm{n}=11(73.3 \%) \\
\mathrm{n}=4(26.7 \%)\end{array}$ & $\begin{array}{l}\mathrm{n}=9(60.0 \%) \\
\mathrm{n}=6(40.0 \%)\end{array}$ & $\begin{array}{c}\chi^{2} \\
1.514\end{array}$ & 0.469 \\
\hline
\end{tabular}

* Significant difference.

n: Number, F: ANOVA test, P: Probability, SD: Standard Deviation, Pulse/min: Pulse per minute, $\chi^{2}$ : Chi Square, RR/min: Respiratory rate per minute, HB gm\%: Blood hemoglobin grams per $100 \mathrm{~mL}$

stay in group-A was significantly longer than in group-B and group-C, while there is no significant difference between group-B and group-C.

As regard zinc serum level before and after manipulation Bose et al. (2006) was in agreement with us, and as regard the effect of zinc supplementation on the course of disease Brooks et al. (2004) and Mahalanabis et al. (2004) were in agreement with the present, while Bose et al. (2006) was disagreed.

By using paired T- test (Table 6) there's significant difference between zinc level before and after in the thirty treated patients (group-B \& group-C), also in group- $\mathrm{B}$ alone and more one in group $-\mathrm{C}$ alone $(\mathrm{P}<0.000)$. 
Table 5: Comparison among the three groups (Mean \pm SD) serum zinc level on day of admission and day of discharge.

\begin{tabular}{|c|c|c|c|c|c|}
\hline Groups & $\begin{array}{c}\text { Group A } \\
\mathbf{n}=15\end{array}$ & $\begin{array}{c}\text { Group B } \\
n=15\end{array}$ & $\underset{n=15}{\operatorname{Group} C}$ & $\begin{array}{l}\text { F- } \\
\text { test }\end{array}$ & $\mathbf{P}$ \\
\hline $\begin{array}{r}\text { Serum zinc before }(\mu m o l / L) \\
\text { Mean } \pm \mathrm{SD} \\
\text { Range }\end{array}$ & $\begin{array}{c}9.09 \pm 0.75 \\
7.9-10.3 \\
\end{array}$ & $\begin{array}{c}8.87 \pm 1.05 \\
7.0-10.2 \\
\end{array}$ & $\begin{array}{c}8.96 \pm 0.86 \\
7.7-10.2 \\
\end{array}$ & 0.22 & 0.800 \\
\hline $\begin{array}{r}\text { Serum zinc after }(\mu m o l / L) \\
\text { Mean } \pm \text { SD } \\
\text { Range }\end{array}$ & -- & $\begin{array}{c}9.60 \pm 0.96 \\
8.0-11.9 \\
\end{array}$ & $\begin{array}{c}11.96 \pm 1.02 \\
10.3-13.3 \\
\end{array}$ & 20.35 & $0.000^{*}$ \\
\hline $\begin{array}{r}\text { Duration before admission } \\
\text { Mean } \pm \text { SD } \\
\text { Range }\end{array}$ & $\begin{array}{c}2.0 \pm 0.92 \\
1-4 \\
\end{array}$ & $\begin{array}{c}1.86 \pm 0.91 \\
1-4\end{array}$ & $\begin{array}{c}1.86 \pm 0.91 \\
1-4\end{array}$ & 0.105 & 0.900 \\
\hline $\begin{array}{r}\text { Hospital days for improvement } \\
\text { Mean } \pm \text { SD } \\
\text { Range }\end{array}$ & $\begin{array}{c}5.66 \pm 3.03 \\
4-15\end{array}$ & $\begin{array}{c}4.66 \pm 1.11 \\
3-6\end{array}$ & $\begin{array}{c}3.66 \pm 0.89 \\
3-6\end{array}$ & 3.987 & $0.026^{*}$ \\
\hline $\begin{array}{r}\text { Total hospital days } \\
\text { Mean } \pm \text { SD } \\
\text { Range }\end{array}$ & $\begin{array}{c}7.53 \pm 3.62 \\
5-18 \\
\end{array}$ & $\begin{array}{c}5.80 \pm 1.20 \\
4-7 \\
\end{array}$ & $\begin{array}{c}4.73 \pm 0.96 \\
4-7 \\
\end{array}$ & 5.796 & $0.006^{*}$ \\
\hline
\end{tabular}

* Significant difference.

n: Number, F: ANOVA test, P: Probability, SD: Standard Deviation, $\boldsymbol{\mu m o l / L : ~ M i c r o m o l e ~}$ per liter.

Table 6: Paired T test for serum zinc level before and after zinc supplemented yoghurt intake.

\begin{tabular}{|l|c|c|c|}
\hline Groups & $\begin{array}{c}\text { Group B \& C } \\
\mathbf{n = 3 0}\end{array}$ & $\begin{array}{c}\text { Group B } \\
\mathbf{n = 1 5}\end{array}$ & $\begin{array}{c}\text { Group C } \\
\mathbf{n = 1 5}\end{array}$ \\
\hline $\begin{array}{r}\text { Items } \\
\text { Merum zinc before }(\boldsymbol{\mu m o l} / \mathbf{L}) \\
\mathbf{M D}\end{array}$ & $8.920 \pm 0.950$ & $8.873 \pm 1.058$ & $8.966 \pm 0.864$ \\
\hline $\begin{array}{r}\text { Serum zinc after }(\boldsymbol{\mu m o l} / \mathbf{L}) \\
\text { Mean } \pm \text { SD }\end{array}$ & $10.786 \pm 1.547$ & $9.606 \pm 0.966$ & $11.966 \pm 1.022$ \\
\hline P for paired T- test & $0.000^{*}$ & $0.005^{*}$ & $0.000^{*}$ \\
\hline
\end{tabular}

* Significant difference.

N: Number, F: ANOVA test, P: Probability, SD: Standard Deviation, $\mathbf{\mu m o l} / \mathbf{L}:$ Micromole per liter.

In general the serum zinc levels in the previous studies of Brooks et al (2004), Mahalanabis et al. (2004), Bose et al. (2006) and Coles et al. (2007) 
were different than ours because the time of blood collection (which occurred at any hour of the day or night throughout the studies) is known to cause variation in plasma zinc concentrations (Hotz et al., 2003).

In agreement with the present results Coles et al. (2007) found that at discharge, mean $( \pm \mathrm{SD})$ plasma zinc concentrations were significantly higher in the zinc group than in the placebo group $(13.0 \pm 2.5$ and $12.0 \pm 4.1 \mu \mathrm{mol} / \mathrm{L}$, respectively; $\mathrm{P}=0.013$ ).

Correlation test shows that there are none significant negative correlation $(\mathrm{P}>0.05)$ between the zinc level and hospital days of improvement and a significant one $(\mathrm{P}=0.006)$ as regard total hospital days (Table 7).

Table 7: Correlation between serum zinc levels (at day of discharge) of the treated patients with supplemented yoghurt and both of the total days of improvement and the total hospital days

\begin{tabular}{|l|c|c|}
\hline Correlation test & $\mathbf{R}$ & $\mathbf{P}$ \\
\hline Hospital days for improvement & -0.336 & 0.07 \\
\hline Total hospital days & -0.491 & $0.006^{*}$ \\
\hline
\end{tabular}

* Significant difference. $\quad$ P: Probability $\quad$ R: Correlation

These results are in line with Brooks et al. (2004) who found that children given zinc recovered from severe pneumonia an average of one day earlier than did those given placebo, and their average stay in hospital was one day longer. The zinc supplement was safe and well tolerated. Since a course of zinc treatment costs only US $\$ 0.15$, and one day staying in hospital costs US $\$ 25$, the potential cost savings are substantial.

Conclusively, from these results it could be concluded that the low serum zinc level due to low dietary zinc intake of children in our community suggests that zinc supplements for the treatment of pneumonia are likely to be effective.

\section{REFERENCES}

A.O.A.C.(1990). Association of Official Analytical Chemists (2000): Official Methods of Analysis. $17^{\text {th }}$ Ed., Vol.1., University of Michigan, USA. pp: 247.

Andy P. (2005): Discovering statistics using SPSS. London, Sage. 2nd ed., Chapter 15. 
Aydemir T. B., Blanchard R. K. and Cousins R. J. (2006): Zinc Supplementation of Young Men Alters Metallothionein, Zinc Transporter, and Cytokine Gene Expression in Leucocyte Populations. PNS.; 103(3):1699-1704.

Bhutta Z. A., Bird S. M., Black R. E., Brown K. H., Gardner J. M., Hidayat A., Khatun F., Martorell R., Ninh N.X., Penny M. E., Rosado J. L., Roy S. K., Ruel M.A., Sazawal S. and Shankar A. (2000): Therapeutic effects of oral zinc in acute and persistent diarrhea in children in developing countries: pooled analysis of randomized controlled trials. Am. J. Clin Nutr.; 72(6):1516-1522.

Bose A., Coles C. L., John H., Gunavathi, John H., Moses P., Raghupathy P., Kirubakaran C., Black R. E., Brooks W. A. and Santosham M. (2006): Efficacy of zinc in the treatment of severe pneumonia in hospitalized children $<2$ y old. Am. J. Clin. Nutr.; 83(5):1089-1096.

Brooks W. A., Yunus M., Santosham M., Wahed M. A., Nahar K., Sultana Y and Black RE (2004): Zinc for severe pneumonia in very young children: double-blind placebo-controlled trial. Lancet.; 363:1683-1688.

Chandan, R. C. and O'Rell, K. R.(2006). Manufacture of various types of yogurt. In: Manufacturing yogurt and fermented milk. R.C. Chandan, C.H. White, A. Kilara and Y. H. Hui (Eds.), Blackwell Publishing Ltd, UK.

Chia-Ni Lina, Wilsonb A. and Churchb B. B. (2012): Pediatric reference intervals for serum copper and zinc. Clinica Chimica Acta; 413(56):612-615.

Coles C., Bose A, Moses P., Leni Mathew, Agarwal I., Mammen T., Santosham M. (2007): Infectious etiology modifies the treatment effect of zinc in severe pneumonia. Am. J. Clin. Nutr.; 86(2): 397-403.

Cousins R. J. (1985): Absorption, transport, and hepatic metabolism of copper and zinc: special reference to metallothionein and ceruloplasmin. Physiol Rev.; 65:238-309.

Eissa E.A., Mohamed Ahmed I.A., Yagoub A. E. A. and Babiker E.E. (2010): Physicochemical, microbiological and sensory characteristics of yoghurt produced from goat milk. Livestock Research for Rural Development; 22 (8):137.

Fontaine O. (2001): Effect of zinc supplementation on clinical course of acute diarrhea. J. Health Popul. Nutr.; 19:339-346. 
Fosmire G. J. (1990): Zinc toxicity. Am. J. Clin. Nutr; 51:225-227.

Fuentea M.A., Montesb F., Guerreroa G. and Juárez M. (2003): Total and soluble contents of calcium, magnesium, phosphorus and zinc in yoghurts. Food Chemistry; 80(4):573-578.

Gaetke L.M., McClain C.J., Talwalkar R.T. and Shedlofsky S.I. (1997): Effects of endotoxin on zinc metabolism in human volunteers. Am. J. Physio.; 272: E952-E956.

Harrigan W. F. and McCance M. E. (1976): Laboratory Methods in Food and Dairy Microbiology, 2nd Ed. Academic Press, London. pp:25-29.

Hotz C., Peerson J.M. and Brown K.H. (2003): Suggested lower cutoffs of serum zinc concentrations for assessing zinc status: reanalysis of the second National Health and Nutrition Examination Survey data (19761980). Am. J. Clin. Nutr.; 78(4): 756-764.

Jones G., Steketee R.W., Black R.E., Bhutta Z.A. and Morris S.S. (2003): How many child deaths can we prevent this year? Lancet.; 362:65-71.

Laye I., Karleskind D. and Morr C.V. (2006): Chemical, Microbiological and Sensory Properties of Plain Nonfat Yogurt. Journal of Food Science; 58(5):991 - 995.

Ling E. R. (1963): Diary Chemistry Textbook. Vol.2, Practical, 3rd ed., Champan and Hall Ltd., London, UK.

Ling P. R., Schwartz J. H. and Jeevanandam M. (1996): Metabolic changes in rats during a continuous infusion of recombinant interleukin-1. Am J Physiol.; 270: E305-E312.

Mahalanabis D., Lahiri M., Paul D., Gupta S., Gupta A., Abdel-Wahed M. and Khaled M. A. (2004): Randomized, double-blind, placebocontrolled clinical trial of the efficacy of treatment with zinc or vitamin A in infants and young children with severe acute lower respiratory infection. Am. J. Clin. Nutr.; 79(3):430-436.

Masud T., Sultana K. and Shah M. A. (1991): Incidence of lactic acid bacteria isolated from indigenous dahi. Australian Journal of Animal Science; 4: 329-331.

Omer S. H. (2004): Chemical and Physical Properties of Yoghurt from Khartoum Dairy product Company (KDPC). Master, Department of Dairy Production, Faculty of Animal Production, Khartoum University, Khartoum, Sudan. Web: http :// etd .uofk. edu/ uofketdallview .php ? id $=3228$. 
Osman M. M. (2004): Effect of fortification with zinc, iron and ascorbic acid on the chemical, microbiological and organoleptic properties of buffalo’s bio-yoghurt. J. Agric. Sci., Mansoura Univ., 29(1):237-251.

\section{دراسة تأثثير الزبادي المدعم بالزنك على صحة الأطفال المصابين بالالتهاب الرئوي الحاد}

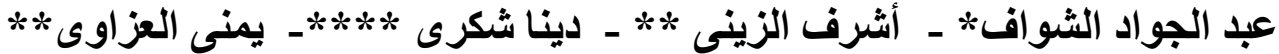

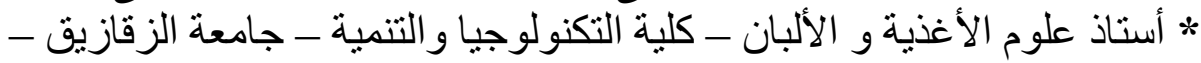

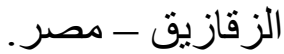

$$
\begin{aligned}
& \text { **قسم الإقتصاد المنزلى ـ كلية التزبية النوعية ـ جامعة الزقازيق ـ الزقازيق ـ مصر. }
\end{aligned}
$$



$$
\begin{aligned}
& \text { *** قمم التغذية و علوم الأطعده ـ كلية التربية النوعية ـ جامعة المنصورة - }
\end{aligned}
$$



$$
\begin{aligned}
& \text { ***** قسم طب الأطفال - كلية الطب - جامعة الزقازيقـ الزقازيق - مصر. }
\end{aligned}
$$

تتأثر صحتنا بما نأكله، و يعتبر الزنك من المكملات الغذائيه الأساسيه لإرتباطه


الزنك فى تركيب كل الخلايا تقريبا فيحفز نشاط أكثر من مائة انزيم مسئولين عن العديد

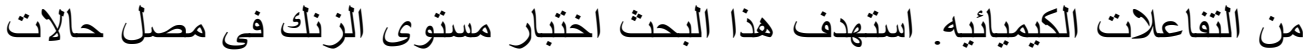

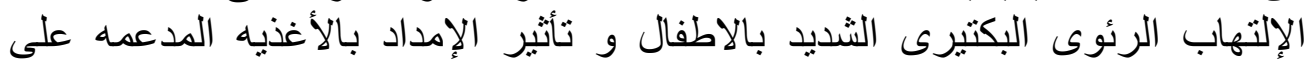



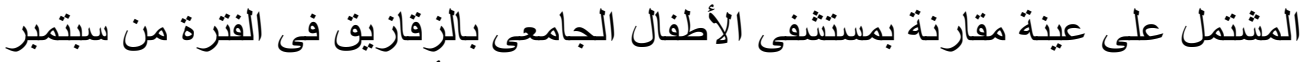

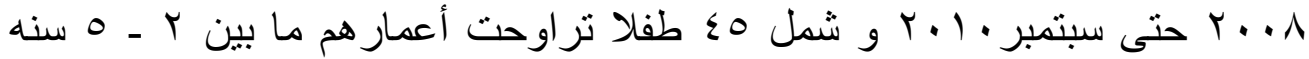

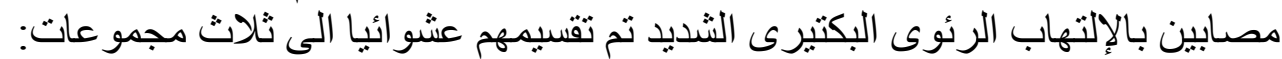



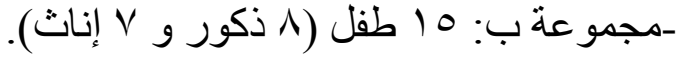


-مجموعة ج: 10 طفل (1 ذكور و V إناث).

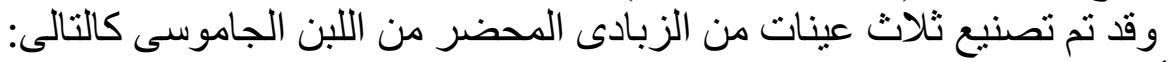

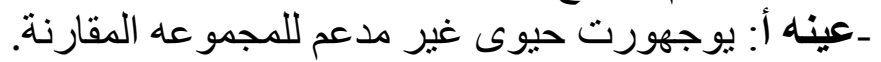

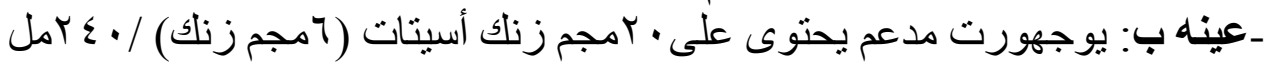

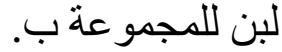

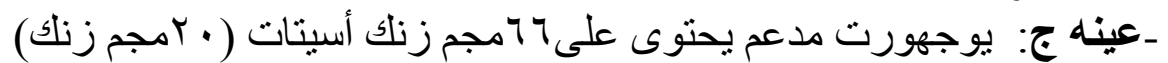

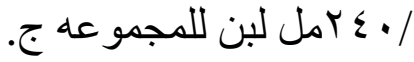
وقد تم اختبار الخو اص الكيميائيه، الطبيعيه و الميكروبيولوجيه للعينات الثنلاث.

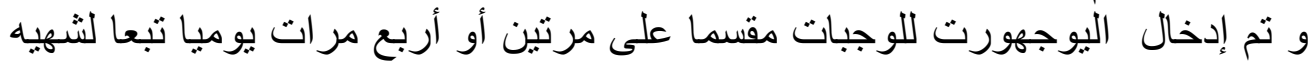

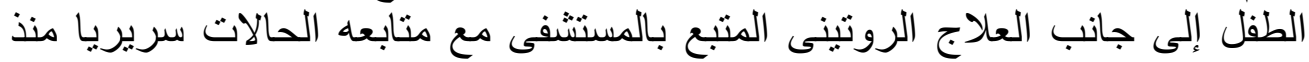

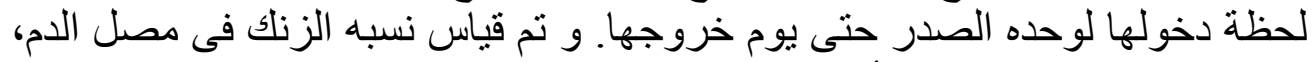

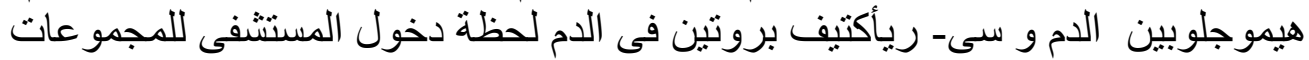
الثلاث كما تم قياس نسبه الزنلك فى مصل الدم وقت فئ الخروج من المستشفى للمجمو عتين


وقد أسفرت النتائج عن تحسن فى مستوى الزنك فى مصل الدم و تقصير فتره

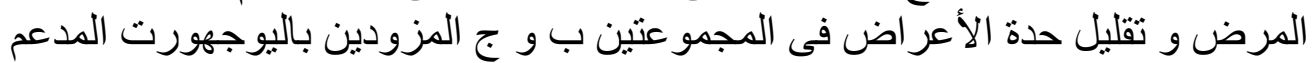

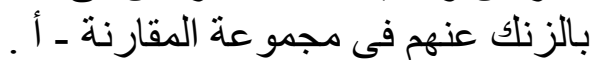

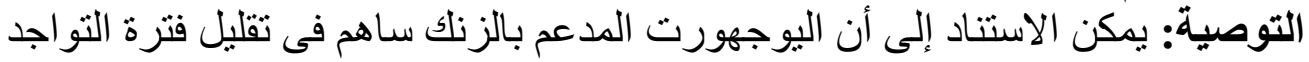

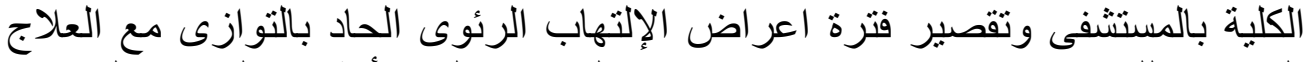

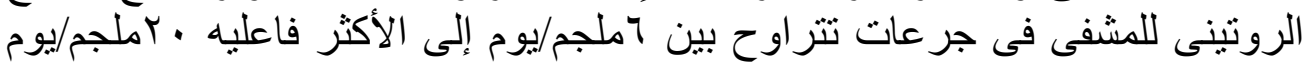
من الزنك كمكمل غذائى ، مما يثبت فاعليه الزنك في التأثير على التى تحسين حاله الجهاز المناعى للأفر اد. 